\title{
Seabird diet analysis suggests sudden shift in the pelagic communities of the subtropical Northeast Atlantic
}

\author{
Joana Romero $^{\mathrm{a},{ }^{*}}$, Paulo Catry ${ }^{\mathrm{b}}$, Hany Alonso $^{\mathrm{c}}$, José Pedro Granadeiro ${ }^{\mathrm{a}}$

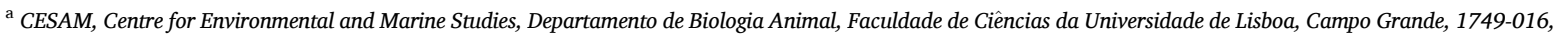 \\ Lisbon, Portugal \\ ${ }^{\mathrm{b}}$ MARE, Marine and Environmental Sciences Centre, ISPA-Instituto Universitário, Rua Jardim do Tabaco 34, 1149-041, Lisbon, Portugal \\ c SPEA, Portuguese Society for the Study of Birds, Avenida Columbano Bordalo Pinheiro 87, 1070-062, Lisbon, Portugal
}

\section{A R T I C L E I N F O}

\section{Keywords:}

Seabirds

Ecosystem change

Pelagic

Canary Current

Calonectris borealis

Macroramphosus scolopax

Scomber colias

Community shift

\begin{abstract}
A B S T R A C T
The dynamics of the subtropical pelagic ecosystems of the Northeast Atlantic are still poorly known due to the high costs associated with sampling large oceanic areas. Top predators can be used as alternative low-cost samplers and indicators of the temporal variability of such systems. To study the variation in the composition of pelagic species through time in the broad Canary current region, we analysed foraging trips and regurgitations of Cory's shearwaters Calonectris borealis nesting on Selvagens islands, in 2008-2011 and 2016-2018. Fisheries data, oceanographic variables and the North Atlantic Oscillation were explored as possible explanatory variables for trends in behaviour and diet. Cory's shearwaters' diet, complemented by fisheries data, revealed marked changes in the composition of the pelagic fish communities. In 2016 there was a peak in the abundance of the Atlantic chub mackerel Scomber colias, followed by an explosive increase in the abundance of the Longspine snipefish Macroramphosus scolopax in 2017 and 2018, as deduced from the diet composition of the Cory's shearwater, and supported by fisheries data, in the broad oceanic area surrounding the Selvagens islands. Oceanographic variables did not show fluctuations correlated with these marked shifts in pelagic fish availability, the causes of which remain largely unknown. This study highlights the importance of the Atlantic chub mackerel and of the Longspine snipefish in the Madeira/Canary region and exemplifies the efficiency of avian predators in revealing rapid changes in pelagic communities of oceanic domains. Such trends and variations need to be better monitored and understood to measure the impact of ongoing global changes and to sustainably manage the marine environment and resources.
\end{abstract}

\section{Introduction}

The high-seas of the subtropical eastern North Atlantic are a nutrientpoor region, contrasting with the richer waters of the strong coastal upwelling of West Africa associated with the Canary Current (Cropper et al., 2014). The existence of seamounts and islands in an otherwise deep-ocean region enhances conditions for many pelagic organisms to thrive in this area (Morato et al., 2008; Pitcher et al., 2007).

Even though predators at high trophic levels dominate the pelagic community with a large number of species in this region, all trophic levels are characterized by a low biomass when comparing with the more productive coastal region (Pitcher et al., 2007). Among these forage fish are the Atlantic chub mackerel Scomber colias (hereafter simply chub mackerel) and the Blue jack mackerel Trachurus picturatus which are some of the most abundant and with higher productivity rates of this type of ecosystem (Hermida and Delgado, 2016). Other vital, but less studied marine organisms, include cephalopods and mesopelagic fish which sustain not only deep-sea fish (Fock et al., 2002a) but also epipelagic feeders, like seabirds (Waap et al., 2017). In addition, their daily vertical migration creates an important link between the depths and the epipelagic domain (Salvanes and Kristoffersen, 2001).

Small pelagic fish have been studied extensively in coastal shelf areas where they often represent commercially important fisheries. In neritic environments, oceanographic variables (e.g. Thiaw et al., 2017) and environmental indexes have been suggested as explanations for the variations and shifts in the reproduction or migration of marine species (e.g. Edwards et al., 2013). The only other pelagic habitat which has been further studied are seamounts (Pitcher et al., 2007). On the other

\footnotetext{
* Corresponding author.

E-mail address: j-romero@live.com (J. Romero).
} 
hand, the open ocean beyond shelf waters is among the least known biomes on Earth because of the logistic and monetary challenges of sampling these areas. Data on the ecology and temporal fluctuations of pelagic species in areas such as the oceanic region around the Madeira and Canary archipelagos, off NW Africa, are still very limited. Here, there have been some attempts to study the composition, abundance and distribution of pelagic and demersal species with the help of research or fishing vessels (Christiansen et al., 2009; Delgado et al., 2018; Fock et al., 2002b). However, these studies were mostly species-directed and few presented a multi-specific approach.

Top predators with high mobility, such as cetaceans, tuna, and seabirds, have been successfully used as tools to sample large areas of the marine environment (e.g. Grebmeier et al., 2006; Pethybridge et al., 2015; Church et al., 2018). Studies on their diet and foraging behaviour enable scientists to gather useful information on the composition and the spatial and temporal distribution of the trophic groups that constitute their prey (Velarde et al., 1994). The Cory's shearwater Calonectris borealis has been the target of long-term studies which have provided important information on their feeding ecology and behaviour (e.g. Alonso et al., 2018, 2012). This pelagic seabird nests in several islands of the Macaronesian region, including the Selvagem islands, a small group of oceanic islands ca. $300 \mathrm{~km}$ south of the Madeira archipelago. During the breeding season, birds from Selvagem typically travel several hundred kilometres in a single foraging trip, targeting pelagic areas around the island, seamounts and also neritic areas over the African continental shelf (Alonso et al., 2018). They are generalist predators, feeding on a variety of (mostly shoaling) pelagic fish and squid species caught during the day near the surface of the ocean (Alonso et al., 2014; Granadeiro et al., 1998). Cory's shearwaters are also known to occasionally interact with underwater predators, like tunas and cetaceans, which drive prey to the surface and make them available to seabirds (Veit and Harrison, 2017).

As an abundance and widespread species in this region, these seabirds are potential indicators of important variations in epipelagic communities that might pinpoint changes in the structure of prey communities. In the present study, we describe the interannual variability of the pelagic community in the broad region surrounding the Selvagens islands, using the Cory's shearwater as a biological sampler. We combined dietary information with the location of their main foraging areas and fisheries data in order to assess the temporal variations in the composition and distribution of the most common pelagic species in the region. Concurrently, we examined the changes in oceanographic variables, to assess the extent to which they might explain the variation of the community in this oceanic area. Finally, we examine the relationship between the observed changes in the diet and the potential consequences for the reproductive success of this species.

\section{Methods}

Fieldwork was carried out at Selvagem Grande island $\left(30^{\circ} 09^{\prime} \mathrm{N}, 15^{\circ}\right.$ 52 ' W, Fig. 1) where data was collected during the chick-rearing seasons of 2008-2011, and 2016-2018.

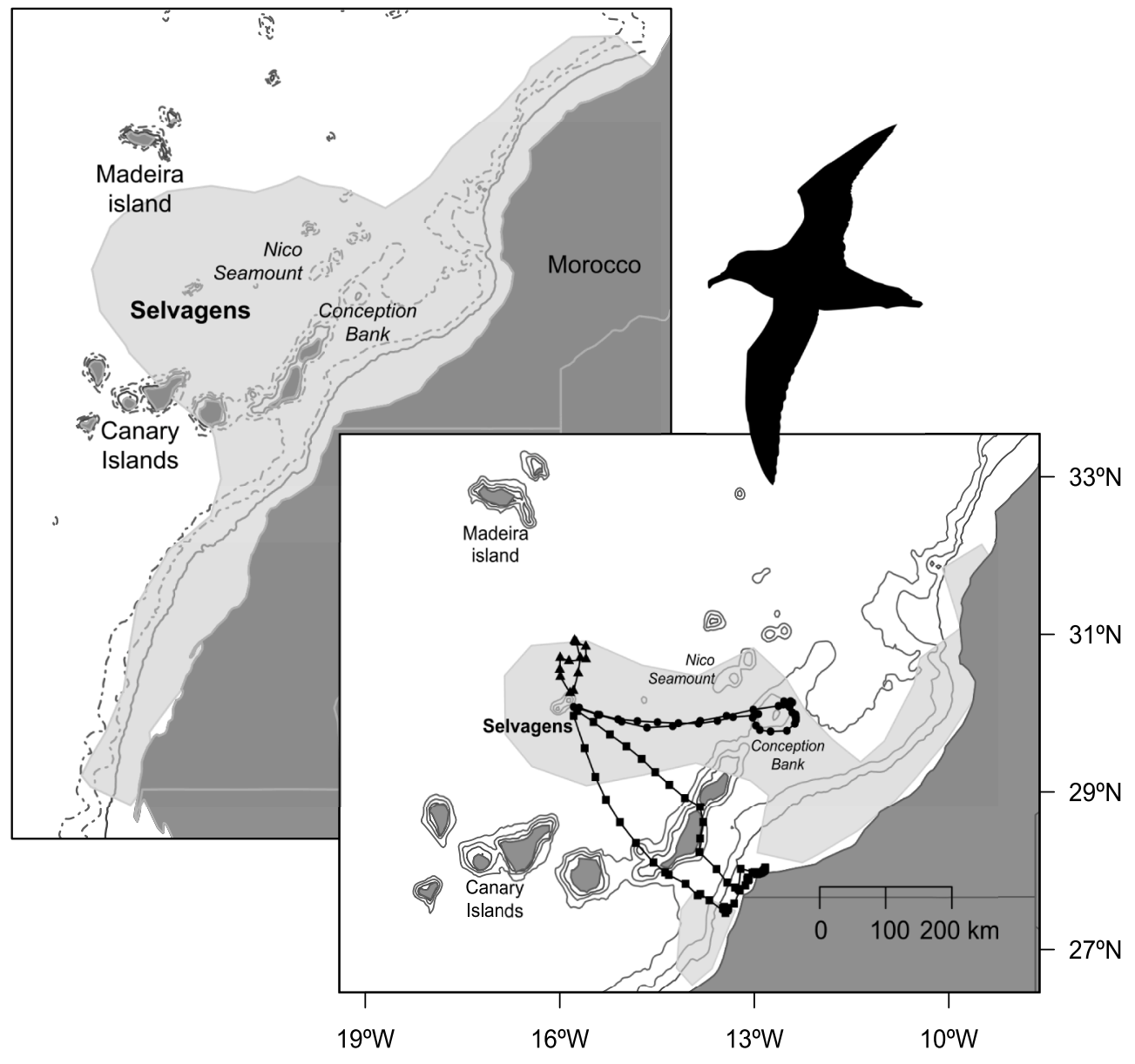

Fig. 1. (A) Foraging areas of Cory's shearwaters Calonectris borealis during the breeding season in Selvagem Grande in 2008-2011 and 2016-2018, as revealed by the present study (shadowed area corresponds to 95\% Kernel Density Estimation). (B) Domains used by Cory's shearwaters during their foraging trips (shadowed areas correspond to 50\% Kernel Density Estimation) and examples of foraging trips to

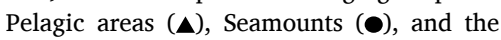
African coast (ם). Isobathic lines of $200 \mathrm{~m}$, $1000 \mathrm{~m}$ and $2000 \mathrm{~m}$ are represented as black lines. 


\subsection{Diet}

\subsubsection{Sampling and identification of prey}

A total of 827 regurgitations were collected between July-late August of 2008-2011 and 2016-2018. Breeding individuals were captured upon their arrival at the nest to feed their chick at dusk and their stomach content was collected by stomach flushing with salt water (Wilson, 1984). Individuals were then marked with colour (livestock paint crayon) to avoid any subsequent disturbance. The stomach content was then carefully sieved to remove excess water and immediately stored in a container and frozen until analysis in the laboratory. Less digested fish prey were identified morphologically to the lowest taxonomic level, using identification guides. Digested items (levels III and IV, following Alonso et al., 2018) were ascribed to species based on our reference collection of fish skeletons and otoliths from the NE Atlantic (over 700 specimens of ca. 100 species).

Whenever the taxonomic identification of a prey by hard structures was not possible, a muscle tissue sample was collected from the remaining bones, stored in $96 \%$ alcohol, and frozen to be identified by DNA barcoding (Alonso et al., 2014). A total of 103 muscle samples belonging to 56 fish and 47 cephalopod prey were collected from Cory's shearwaters regurgitations. DNA was extracted from these samples using the E.Z.N.A. Tissue DNA kit (Omega Bio-tek). The $3^{\prime}$ end region of the 16S rRNA gene of fish and cephalopod DNA was amplified with the universal primers 16Sar and 16SSbr (Palumbi, 1996) using optimized PCR conditions (Alonso et al., 2014). The PCR products were sequenced in both directions in outsourcing (Macrogen Inc). The resulting sequences were used in BLAST (NCBI) searches and similarity values higher than $98 \%$ were considered as a positive identification for the queried sample.

For the purpose of this study we did not distinguish between different Chub mackerel species and refer to them as Scomber sp., as several prey items were only identified to genus level. Nevertheless, only chub mackerel Scomber colias was identified to species level within the samples. Eroded cephalopod beaks were not included in the analysis of the diet because they tend to remain in the stomach of seabirds for long periods (weeks) after ingestion, resulting in an over-representation of this group when they are included.

\subsubsection{Data analysis}

All fish found whole in the regurgitations were weighted (wet weight, $\pm 0.1 \mathrm{~g}$ ) and measured (standard length, $\pm 1 \mathrm{~mm}$ ). Whenever that was not possible, fish size was estimated from the size of specific vertebrae using published equations (Granadeiro and Silva, 2000). The standard length (SL) of Pilotfish was estimated from the length of the first caudal vertebrae (CV); $1^{\text {st }} \mathrm{CV}$; $S L=1.602+1^{\text {st }} \mathrm{CV} \times 29.998, \mathrm{r}^{2}=$ $0.98, \mathrm{n}=14$ (SL $=30-118 \mathrm{~mm}$ ) (H. Alonso, unpubl.).

Numeric frequencies (NF, number of individuals of a given prey type as a percentage of the total number of prey items), and frequencies of occurrence (FO, number of samples with a given prey type as a percentage of the total number of samples) were calculated for each prey species (or lowest taxonomic level identified for a prey item) and year.

A Permutational Multivariate Analysis of Variance (PERMANOVA) was performed to check for significant differences in the diet of the Cory's shearwater among years. The PERMANOVA was carried out using the $\mathrm{R}$ vegan package with Jaccard similarities on prey presence/ absence in regurgitations (FO) (Oksanen et al., 2019). In order to compare the diet diversity of this species among years, the Shannon-Wiener diversity index $\left(H^{\prime}\right)$ was calculated for numeric frequency. To avoid bias due to the different number of samples collected in each year, we resampled the smallest number of samples collected ( $\mathrm{n}$ $=30$ ) and carried it out 1000 times for each year. Means and standard deviations were then calculated from those values.

\subsection{GPS deployment and foraging trip analysis}

GPS-loggers were deployed in a total of 150 breeding Cory's shearwaters during the chick rearing season of 2009-2011 (12, 24, and 43 individuals, respectively), 2016 (43) and 2018 (28). The weight of GPS devices (iGotU GPS loggers, $17 \mathrm{~g}$ ) represented ca. $2 \%$ of the average weight of an adult Cory's shearwater, therefore unlikely to have deleterious effect on the behaviour of birds (Phillips et al., 2003). GPS loggers were attached to four central tail feathers with TESA tape, and deployed in the nests at dusk, while the adults were visiting the chicks. Upon return from the feeding trip, the bird was recaptured, and the GPS retrieved. Most trips lasted between one and three days $(79 \%, n=306)$, although some lasted up to 11 days.

Positional data were downloaded from the loggers and divided into separate feeding trips, each starting and ending in Selvagem island. A total of 306 trips were discriminated from the data. Different GPS loggers were programmed to collect fixes between $10 \mathrm{~min}$ and $60 \mathrm{~min}$ intervals. Consequently, in order to allow for comparison among birds, all trips were processed to only include hourly positions, discarding all remaining fixes.

Area utilization was calculated with Kernel Density Estimation (KDE) using the R software package adehabitatHR (Calenge, 2015). The home-range and the main foraging areas were considered as those comprising $95 \%$ and $50 \%$ of the positions, respectively. We compared home ranges and foraging areas of different years using the Utilization Distribution Overlap Index (UDOI), made available through function kerneloverlap.

The $50 \% \mathrm{KDE}$ created by the combination of all trips, revealed 4 main foraging domains: Selvagem $(2000 \mathrm{~m}$ bathymetric line around the Selvagem archipelago); Pelagic (circle with a $160 \mathrm{~km}$ radius around Selvagem and with depths between 2000 and 4000m); Seamounts ( $2000 \mathrm{~m}$ bathymetric line around the seamounts) and African coast (area defined by latitudes $20-35^{\circ} \mathrm{N}$ and $80 \mathrm{~km}$ offshore) (Alonso et al, 2012, 2018) (Fig. 1B). Due to different oceanographic conditions, the African Coast area was further subdivided into Strong Permanent Upwelling Region (SUR, 20-26 N) and Weak Permanent Upwelling Region (WUR, $26-35^{\circ} \mathrm{N}$ ) (Cropper et al., 2014), creating five domains with different environmental features. One of these domains was assigned to each feeding trip as its destination. The destination was assigned as the domain with the highest number of positions of that trip (and the most convoluted part of the track), which was usually also the area with the farthest locations from the colony. Birds sometimes crossed more than one oceanographic domain, but one of these was much more used than the others.

The frequency of occurrence of each foraging domain was calculated to quantify its use by Cory's shearwaters each year. Permutational multivariate analysis of variance (PERMANOVA) was used to test for interannual variability in foraging areas and was carried out using the vegan package with Jaccard similarities on destination of each foraging trip (Oksanen et al., 2019). To calculate the maximum distances from the colony reached by each individual, distances between each position and Selvagem were calculated using the function spDistsN1 from the package $s p$ (Pebesma and Bivand, 2005). Differences among years in maximum distances from the colony were tested using a one-way ANOVA. All statistical analyses were performed using the Software R (version 3.5.2).

\subsection{Fisheries and environmental data}

The total annual landings of chub mackerel from Madeira island from local purse-seiners were obtained from the Regional Direction of Fisheries of the Autonomous Region of Madeira and used as an indicator of the abundance of this species between 2008 and 2018.

Monthly $4 \mathrm{~km}$ AQUAMODIS Chlorophyll $a$ (Chla) and SST data were downloaded from the ERDDAP data server (https://coastwatch.pfeg. noaa.gov/erddap/index.html). Monthly $0.125^{\circ}$ zonal (u) and 
meridional (v) wind components at $10 \mathrm{~m}$ were downloaded from the European Centre for Medium-Range Weather Forecasts (ECMWF) using the ERA-Interim server (https://apps.ecmwf.int/datasets/). The NAO index was obtained from the Climate Data Guide server (https://climat edataguide.ucar.edu/climate-data/hurrell-north-atlantic-oscillation-na o-index-station-based). Data on these variables were obtained for January to April (hereafter "Winter", corresponding to the strongest period of upwelling off the African coast and, thus, the highest Chl a values) and June to September (hereafter "Summer", corresponding to our study period and second peak in Chl a) between 2008 and 2018, to assess seasonal and interannual variability (Davenport et al., 1999). Each variable was averaged within the domains. To do that, the median value of each month was obtained for each domain, and then we calculated the mean for each season. Mean $\mathrm{Chl}$ a values were then log transformed for further analysis. Climatic (NAO) and environmental (Chl a, SST, Wind speed and direction) variables were analysed for correlation with the prey occurrence and with the frequency of occurrence of Cory's shearwaters in different domains throughout the study period. Analyses of variance (ANOVAs) were performed to assess differences among years, seasons and domains.

\subsection{Breeding success}

Throughout the breeding seasons of 2008-2011 and 2016-2018, in Selvagem Grande, between 296 and 349 breeding pairs of Cory's shearwaters were followed each year as part of a long-term demographic study. Successes and failures were registered and the hatching success (percentage of laid eggs that hatched; Cory's shearwaters lay one single egg per year), fledging success (percentage of hatched chicks that survived to fledging age), and the breeding success (hatching success $\times$ fledging success $=$ percentage of chicks fledged per egg laid) were calculated as a measure of reproductive performance.

\section{Results}

\subsection{Foraging ecology of the Cory's shearwater}

We counted a total of 2775 prey individuals in regurgitations, $79 \%$ of which were successfully identified to species, genus or family level, resulting in 47 identified species/genus of 32 identified families (see Supplementary Materials, Table A.1). Fish were the most consumed prey across all years, both in terms of number of individuals (NF range $=$
68.7-99.2\%) and in occurrence (FO range $=87.1-100 \%$ ). Cephalopods were always present throughout the study period ( $\mathrm{NF}$ range = 0.8-26.7\%; FO range $=10.0-50.0 \%$ ) (see Supplementary Materials, Table A.1). Overall, chub mackerel was the most common prey found in the regurgitations of Cory's shearwater from 2008 to 2011 and in 2016, followed by Pilotfish Naucrates ductor, European pilchard Sardina pilchardus and Flying-neon squid Ommastrephes bartramii (Fig. 2). In 2017, Longspine snipefish Macroramphosus scolopax appeared as the most numerous prey ( $\mathrm{NF}=61.5 \%$, Fig. 2), occurring in $53 \%$ of the samples. This situation persisted in 2018 with snipefish dominating the diet (NF $=95.3 \%$ and $\mathrm{FO}=87.5 \%$ ). We found significant differences between years in the diet composition of this shearwater (PERMANOVA: $\mathrm{F}_{6,820}=$ 13.202, $\mathrm{r}^{2}=0.08, \mathrm{p}<0.01$ ).

In 2017 and 2018 the Shannon-Wiener diversity index reduced abruptly to $\mathrm{H}=1.36 \pm 0.24$ and $\mathrm{H}=0.24 \pm 0.05$, respectively, compared with the previous years' mean ranges: $\mathrm{H}=2.19-2.61$ in 2008-2011, and $\mathrm{H}=1.75 \pm 0.20$ in 2016.

The average standard length of the Longspine snipefish was $78.5 \mathrm{~mm}$ (range:51.7-115.9 mm, $\mathrm{n}=516$ ), with no differences among the 3 years (ANOVA: $F_{2,512}=0.92, p=0.39$, See Supplementary materials, Figure A.1). Cory's shearwater fed on Pilotfish with standard lengths of 90.7 mm (range: $24.3-225.6 \mathrm{~mm}$ ). See Supplementary materials for further information on the standard length of prey of Cory's shearwaters (Table A.2).

The destination of foraging trips also presented important differences among years (PERMANOVA: $\mathrm{F}_{5,300}=11.73, \mathrm{r}^{2}=0.16, \mathrm{p}<0.01$, Fig. 3 ). From 2009 to 2011, the African coast was the most used foraging destination $(52 \pm 11 \%)$. However, in 2016, most trips targeted the Selvagem domain and its surroundings (FO $=28 \%$ and $\mathrm{FO}=36 \%$, respectively), and in 2018, the Pelagic domain was the most frequently used (FO $=82 \%$ ). Overall, trips in 2016 and 2018 were closer to the colony comparing to other years, presenting average maximum distances from the colony of 121.6 and $91.6 \mathrm{~km}$, respectively. Even though, 2016 presented a higher number of shorter trips than in 2018. Trips from 2016 to 2018 were significantly different from trips from 2010, 2011 and 2013 (ANOVA: $\mathrm{F}_{5,312}=12.21, \mathrm{p}<0.01$ followed by post-hoc test Tukey HSD, Fig. 4).

The total annual landings of chub mackerels in the archipelago of Madeira from 2008 to 2018 showed no down trend that could imply a reduction in the availability of the species (Fig. 5). It is worth noting that in 2018, when this fish almost disappeared from the diet of Cory's shearwaters, catch levels by human fisheries were not unusually low

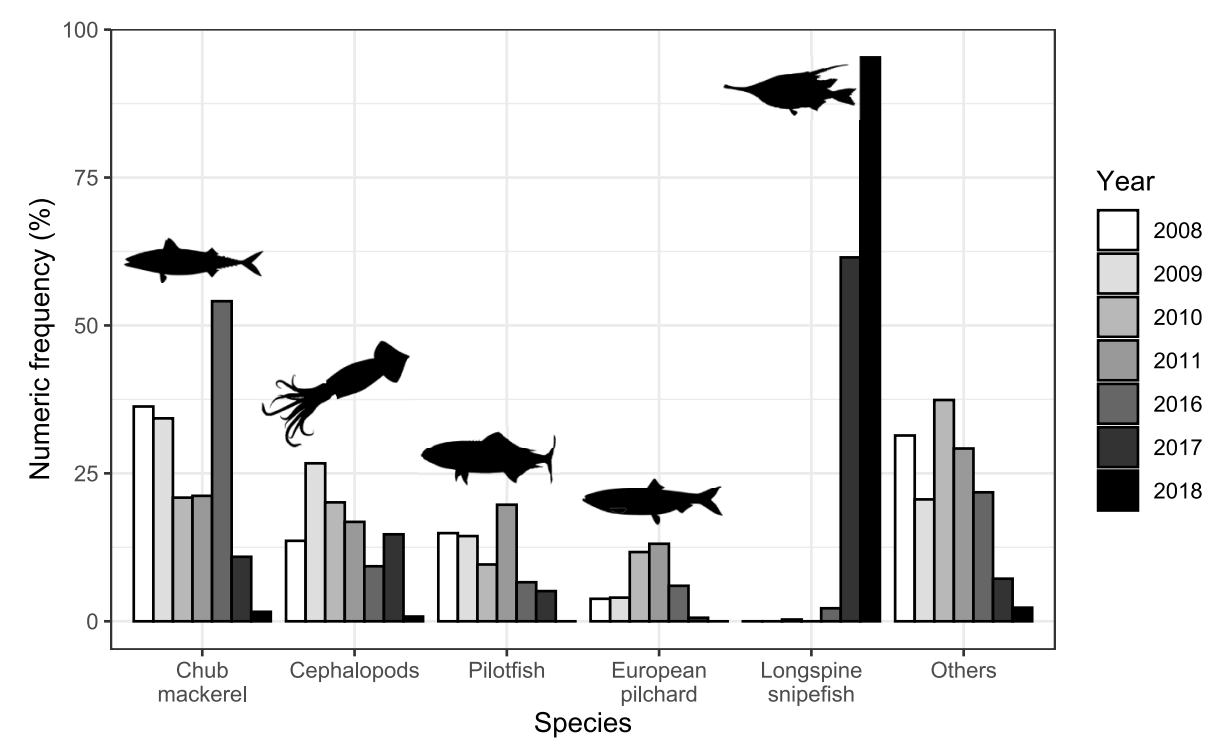

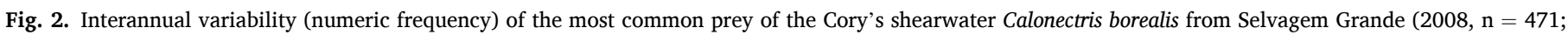
2009, $\mathrm{n}=703 ; 2010, \mathrm{n}=633 ; 2011, \mathrm{n}=137 ; 2016, \mathrm{n}=183 ; 2017, \mathrm{n}=156 ; 2018, \mathrm{n}=492$ ). Detailed data in Supplementary Materials, Table A.1. 


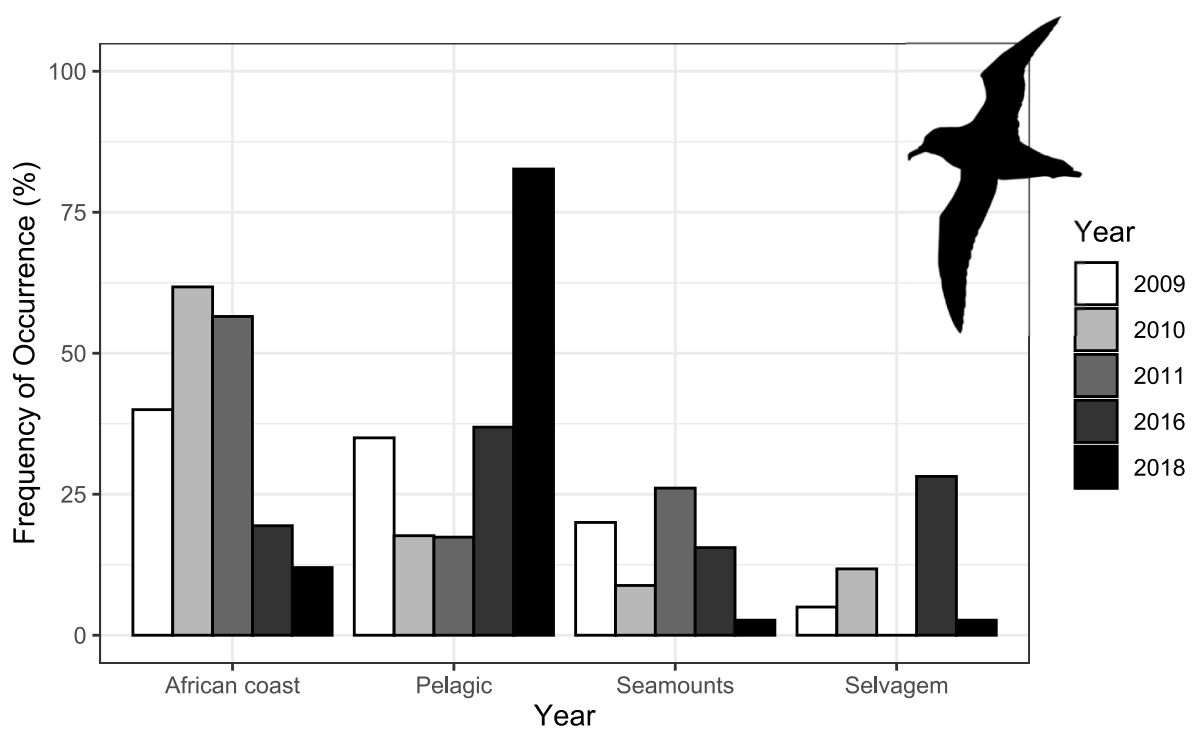

Fig. 3. Percentage of use of different oceanic domains (FO\%) by Cory's shearwaters Calonectris borealis during the chick-rearing phase of 2009-2011 ( $\mathrm{n}=20$, 34, 46, 28, respectively), 2016 ( $n=103), 2018(n=75)$. Data from Weak Permanent Upwelling Region and Strong Permanent Upwelling Region were combined ("African coast").

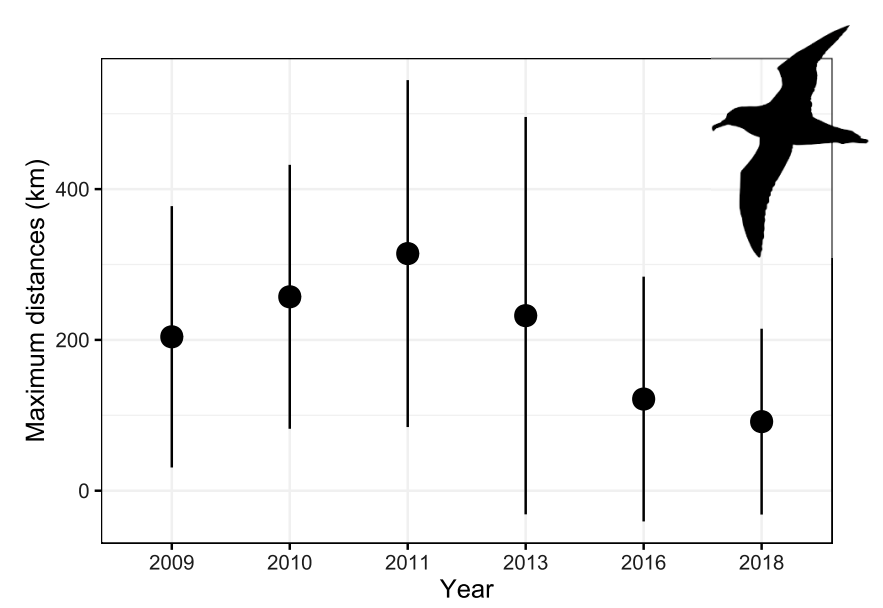

Fig. 4. Average (SD) maximum distance (Km) reached by Cory's shearwaters Calonectris borealis, in each trip per year.

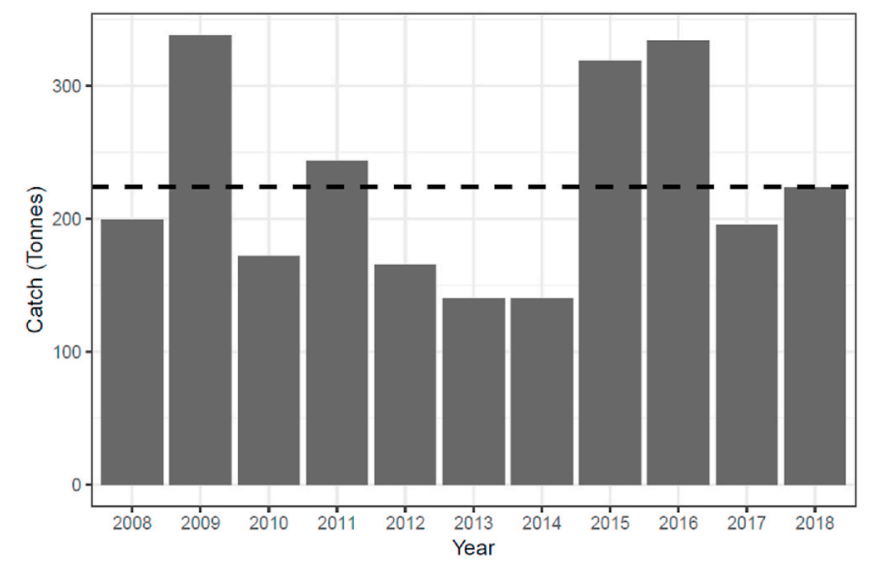

Fig. 5. Variation in the total annual landings and mean catch value $(224$ tonnes, dashed line) of Atlantic chub mackerel Scomber colias in Madeira island for the decade of 2008-2018.
(Fig. 5). The correlation between the numeric frequency of chub mackerels and landings showed to be positive but not quite attaining statistical significance $(r=0.63, p=0.13)$.

\subsection{Environmental and oceanographic characteristics of foraging areas}

Overall, the defined domains showed a similar annual pattern in the SST, Chl a and wind components, but their mean values differed, except the Selvagem and Pelagic domains which were indistinguishable (see Supplementary Materials, Table A.3 and Figure A.2). No correlation was found between any of the oceanographic and meteorological (NAO) variables studied and the proportions of various prey in the diet of Cory's shearwaters (see Supplementary Materials, Table A.4) either in Winter or Summer.

\subsection{Breeding success}

Breeding success only varied slightly during the studied period of 2008-2011 (72.1-75.4\% in 2008-2010 and 63.8\% in 2011) and 2016-2018 (71.3-76.7\%).

\section{Discussion}

Cory's Shearwaters are opportunistic feeders which used different foraging domains within our study area, ranging far from their breeding colony (Fig. 1, see also Alonso et al., 2018). We took advantage of this to gather information on prey in these waters for a total of 7 years using the combination of GPS-tracking and diet data, which provided useful indications concerning the likely origin of their pelagic prey (Alonso et al., 2018). In 2016, the population of chub mackerel showed a peak of abundance in the waters surrounding Selvagens. More noticeably, since 2017 Longspine snipefish suddenly became the dominant prey-item of Cory's shearwaters, mostly captured in the pelagic domain adjacent to Selvagens islands. Fisheries data indicate that the dietary shift of this seabird was not associated with any noticeable decrease of chub mackerel in the region. Hence, our Cory's shearwater diet dataset strongly suggests a major shift in the epipelagic fish communities of this little-known region, with a sudden and dramatic expansion of a previously scarce species, the Longspine snipefish.

From 2008 to 2011, the main prey of Cory's shearwaters from Selvagem Grande colony was the chub mackerel. Chub mackerels are 
widely distributed in the NW African region, in deep-sea areas, seamounts, and continental and island shelves (Alonso et al., 2018; Pitcher et al., 2007; Stromme et al., 2006; Wienerroither et al., 2009). Such large distribution might explain its importance in the diet of Cory's shearwaters (Alonso et al., 2018). A positive correlation (which failed to reach significance, possibly due to the small number of sampled years) between the landings of chub mackerel and its numeric frequency supports the hypothesis that the diet of Cory's shearwaters may provide broad indication of the abundance of this species. However, it would be important to sample more years and for a longer period of time to validate this assumption. While it is difficult to know where chub mackerels are most abundant, it is possible to state that they were very abundant in the Selvagem domain in 2016. In this year, Cory's shearwaters frequently foraged around Selvagem Grande $(\mathrm{FO} \%=28 \%)$ and adjacent pelagic waters $(\mathrm{FO} \%=36 \%)$ and fed mostly on chub mackerels $(\mathrm{NF}=55 \%$ and $\mathrm{FO}=70 \%)$. The peak in total annual landings of chub mackerels observed in Madeira (this study) and in the African coast (Morocco to Senegal, including the Canary islands, 400,000 tonnes; FAO, 2018) in that same year fit well with the peak that we recorded around Selvagem islands. The increase of the population at that time is further confirmed by acoustic surveys performed along the African coast in 2016-2017 (FAO, 2019).

From 2009 to 2011, the African coast was the domain where Cory's shearwaters foraged the most. There, the community of forage fish is mainly composed by European pilchards, which represent $45 \%$ of catch contribution of small pelagic fish (FAO, 2018). From 2008 to 2010, there was a slight increase in the total annual catches of the European pilchard (FAO, 2018) which coincides with the increase of European pilchards in Cory's shearwater diet. In 2016, the proportion of pilchards in the diet did not follow the new increase of landings described in FAO (2018). This can be explained by a reduction in the use of the African coast by Cory's shearwaters due to the apparent increase of chub mackerel around Selvagem.

Pilotfish which are generally found in association with floating structures (juveniles) or large marine species (adults) in pelagic ecosystems (e.g. Riera et al., 1999), were also a common pelagic prey of Cory's shearwaters. Throughout the period of 2008-2011 and 2016-2017, this seabird preyed upon Pilotfish with sizes between 24 and $230 \mathrm{~mm}$, which correspond to juveniles of up to 5 month old (Vassilopoulou et al., 2005). The near-constant presence of this age-group in the diet of Cory's shearwaters during this period is an indicator that they were feeding on new recruits every year.

Besides fish, cephalopods were also an important prey group in the diet of the Cory's shearwater. In our study, 30\% of the cephalopods found in the stomachs of this seabird were Neon-flying squid Ommastrephes bartramii or belonged to the Ommastrephidae family. This is the most common cephalopod family in the Canary Current System, and the Neon-flying squid is among the most common species off North Africa (Hastie et al., 2009). The small variation in the occurrence of flying squids in the diet of the Cory's shearwater in the study years of 2008-2017 indicates a regular presence of this species in the pelagic waters off NW Africa.

In 2017, Cory's shearwaters from the Selvagem colony shifted their diet to feed mostly on Longspine snipefish. In the following year, the importance of this fish in the diet of this seabird further increased to 95.3\%, and the pelagic areas around the archipelago of Selvagens replaced the Selvagem domain and adjacent waters as the main foraging grounds of the Cory's shearwater. The high abundance of the chub mackerel in the African coast and the Canary Islands, in 2017 and 2018 (FAO, 2019) implies that the consumption of the Longspine snipefish was not a result of a shortage of the traditional prey, but a choice. Therefore, we conclude that the trophic shift observed for this seabird reflects an increase in the availability of Longspine snipefish in the pelagic waters around Selvagem in $2017 / 2018$. Such an increase very close to the nesting colony probably allowed Cory's shearwaters to have access to high quantities of food with low effort, even if less caloric
(Martins et al., 2004), rather than targeting alternative, more nutritious prey farther away, which agrees with the classic optimal foraging theory and central place foraging (Bartumeus and Catalan, 2009). Thus, should Longspine snipefish have been abundant close to the colony in previous years, then these seabirds would not have travelled to the African coast to forage. Despite the possible link between a change in the foraging area and a shift in prey consumed, the foraging behaviour of seabirds is known to be influenced by extrinsic factors that are related to prey availability and not by a random choice of foraging areas (Shealer, 2002). Furthermore, between 2016 and 2018, the foraging areas remained the same but with a shift in the diet of Cory's shearwaters from chub mackerels to snipefish, which suggests that the foraging area was not the reason for the shift in diet. For this reason, the shift in the diet is much more likely to be a result of the shift in the prey community of that specific area than solely a change in the foraging area.

Snipefish found in the regurgitations of Cory's shearwater had a mean length of $78.5 \pm 59.1 \mathrm{~mm}$, which did not vary during the study years. These sizes correspond to snipefish slightly younger than one year (Ehrich, 1976; Lopes and Farinha, 1996), possibly resulting from the spawning of December-March (Lopes and Farinha, 1996). The yearly occurrence of snipefish with these standard lengths in the diet of the Cory's shearwater allows us to conclude that the birds were preying on new recruits every year which, consequently, leads us to hypothesize that snipefish were reproducing successfully in the region from 2016 to 2018.

The distribution of the Longspine snipefish in the North Atlantic ranges in latitude from the Iberian Peninsula down to North Mauritania, including varied environments such as shelves and upper slopes, and seamounts (Ehrich et al., 1987). Marked fluctuations in Longspine snipefish abundance have been recorded in other regions of the NE Atlantic. On the Portuguese continental shelf, the only area monitored regularly through systematic surveys (Borges, 2000; Lopes et al., 2006; Lopes and Farinha, 1996; Marques et al., 2005), the snipefish population presented high abundances in the 1970's (annual landings: 10,000 tonnes in 1973, and 33,000 tonnes in 1978) (Morais, 1981), and late 1990 's/early 2000's (acoustic estimates: 500,000 tonnes in 1998 to 175, 000 tonnes in 2003) (Marques et al., 2005), with low abundances in the 1980's (Marques et al., 2005). Seemingly, these fluctuations coincided with abrupt fluctuations in other areas. Outbursts were described in the coast of Morocco (Arístegui et al., 2004) and in the Azores (Granadeiro et al., 1998; Ramos et al., 1998) in the 70's (acoustic survey: 1,000,000 tonnes in 1976 to disappear in the 80's) and the 90's (1994-1995), respectively. In 2005, dietary data from Cory's shearwaters provided some evidence of the decrease in abundance of snipefish in the Azores comparing with the 90's (Xavier et al., 2011). The Longspine snipefish was considered abundant in the Seine Seamount (located northeast of Madeira) in 2003-2005, and in the Meteor Seamount (located in the middle of the Atlantic, west of Madeira) in 1967, 1970 and 1998 (Christiansen et al., 2009; Fock et al., 2002b; Zidowitz and Fock, 2004).

Studies have shown that the appearance and disappearance of Longspine snipefish throughout time can alter considerably the trophic web, with predators suddenly shifting their diet to this prey once its numbers increase (e.g. Morato et al., 1999; Silva 1999). Snipefish is an important prey (at some times and locations the main prey) of seabirds, sharks, dolphins, tunas, rays, hakes and John Dory Zeus faber (e.g. Granadeiro et al., 1998; Morato et al., 1999; 2003; Silva 1999; Zidowitz and Fock 2004). To what extent snipefish can influence the functioning of the ecosystems when their numbers change is still uncertain. In our study, Cory's shearwaters, which like many seabird species are sensitive to prey fluctuations (Becker et al., 2007; Kowalczyk et al., 2014), did not show signs of having been affected by this major shift in their main prey. Despite a radical shift in diet, between 2016 and 2018, the breeding success remained largely unchanged. This also suggests that snipefish can be a valuable resource for pelagic predators.

What drives the Longspine snipefish wide population fluctuations is still unknown, and we did not find changes in oceanographic variables 
that correlated with the increase of this species' abundance reported here. The sudden proliferation of some marine taxa can sometimes be associated with the disappearance of a dominant species (predators or competitors) due to fisheries or environmental changes (Caddy and Rodhouse, 1998; Gulland and Garcia, 1984). The increase of snipefish in our study was apparently not linked with the decrease of any other abundant species, according to fisheries data (FAO, 2019). So, the reasons for such successful consecutive recruitments is yet to be discovered.

The Cory's shearwater is considered to be a generalist predator, but it is important to point out that Cory's shearwaters are surface feeders and shallow divers, reaching an average depth during foraging trips of only 2.7m (Mougin and Mougin, 1998). Hence, they cannot be considered totally unbiased samplers of the whole marine environment. Their diet will thus reflect availability in surface waters, rather than overall abundance of fish stocks. Nevertheless, it is reasonable to assume that availability in surface waters correlates with overall abundance, even if imperfectly so. It is also known that the action of subsurface predators can bring more prey to surface waters, and should their abundance drastically change, this could have an important influence in the diet of Cory's shearwaters. However, we know of no evidence for drastic changes in the community of underwater predators which might explain the very major shift in the diet of the Cory's shearwaters observed in this study.

This study exemplifies how biological samplers like Cory's shearwaters can provide novel information about important changes in epipelagic ecosystems, that would otherwise be difficult to detect. Previous studies have already shown the usefulness of seabirds as bioindicators of their foraging areas and prey, unveiling annual fluctuations of fish stocks (e.g. Scopel et al., 2018) and changes in the food web and in oceanographic conditions (e.g. Montevecchi, 2007). The major shifts in the epipelagic fish community around Selvagens archipelago revealed by this study and the lack of known environmental correlates for such shifts underscore our poor understanding of the dynamics of key-species in little known subtropical pelagic waters. Such trends and variations need to be better monitored and understood if we are to measure the impact of ongoing global changes and to sustainably manage the broad marine environment and resources.

\section{CRediT authorship contribution statement}

Joana Romero: Conceptualization, Methodology, Formal analysis, Writing - original draft. Paulo Catry: Conceptualization, Methodology, Formal analysis, Resources, Writing - original draft, Writing - review \& editing, Supervision, Project administration, Funding acquisition. Hany Alonso: Methodology, Formal analysis, Writing - original draft, Writing - review \& editing. José Pedro Granadeiro: Conceptualization, Methodology, Formal analysis, Resources, Writing - original draft, Writing review \& editing, Supervision, Project administration, Funding acquisition.

\section{Declaration of competing interest}

The authors declare that they have no known competing financial interests or personal relationships that could have appeared to influence the work reported in this paper.

\section{Acknowledgements}

This work was supported by Fundação para a Ciência e a Tecnologia (FCT Portugal) through the project Oceanwebs (PTDC/MAR-PRO/ 0929/2014) and Seamigrant (PTDC/BIA-ANM/3743/2014), the strategic projects UIDB/04292/2020 and UIDP/04292/2020 granted to MARE, and UIDB/50017/2020 and UIDP/50017/2020 granted to CESAM. PD/BD/127810/2016 was granted to JR by FCT. We would like to acknowledge Serviço do Parque Natural da Madeira and Instituto das Florestas e Conservação da Natureza, specially Dr. Paulo Oliveira and
Dr. Carolina Santos, for providing the required permits to undertake experiments with birds and logistical support to carry out the work at the islands of Selvagens. All procedures were carried out following a positive recommendation from the Animal Welfare Regulatory Body of the Faculty of Sciences of Lisbon University and were carried out under licenses issued by the Direção Geral de Alimentação e Veterinária, license number DGAV 0421/2016. Thanks are due to Direção Regional de Pescas da Madeira, specially to Dr. Graça Faria, for providing data on the annual landings of small pelagic fishes. Filipe Moniz for helping during the field and laboratory work. We also thank to Letizia Campioni, Diana Barão, Teresa Catry, Maria Alho and Marie Claire for helping during field work and giving further insights for this study, and to park-wardens Carlos Clemente, Carlos Santos, Jaques da Mata, João Paulo Mendes, Maurício Baptista, Marco Camacho and Fernando. No conflicts of interest.

\section{Appendix A. Supplementary data}

Supplementary data to this article can be found online at https://doi. org/10.1016/j.marenvres.2020.105232.

\section{References}

Alonso, H., Granadeiro, J.P., Dias, M.P., Catry, T., Catry, P., 2018. Fine-scale tracking and diet information of a marine predator reveals the origin and contrasting spatial distribution of prey. Prog. Oceanogr. 162, 1-12. https://doi.org/10.1016/j. pocean.2018.02.014.

Alonso, H., Granadeiro, J.P., Paiva, V.H., Dias, A.S., Ramos, J.A., Catry, P., 2012. Parentoffspring dietary segregation of Cory's shearwaters breeding in contrasting environments. Mar. Biol. 159, 1197-1207. https://doi.org/10.1007/s00227-0121900-2.

Alonso, H., Granadeiro, J.P., Waap, S., Xavier, J., Symondson, W.O.C., Ramos, J.A., Catry, P., 2014. An holistic ecological analysis of the diet of Cory's shearwaters using prey morphological characters and DNA barcoding. Mol. Ecol. 23, 3719-3733. https://doi.org/10.1111/mec.12785.

Arístegui, J., Álvarez-Salgado, X.A., Barton, E.D., Figueiras, F.G., Hernández-León, S., Roy, C., Santos, A.M.P., 2004. Oceanography and fisheries of the canary current/ iberian region of the eastern North atlantic (18a, E). In: The Sea, pp. 877-932.

Bartumeus, F., Catalan, J., 2009. Optimal search behavior and classic foraging theory. J. Phys. Math. Theor. 42, 12pp. https://doi.org/10.1088/1751-8113/42/43/ 434002.

Becker, B.H., Peery, M.Z., Beissinger, S.R., 2007. Ocean climate and prey availability affect the trophic level and reproductive success of the marbled murrelet, an endangered seabird. Mar. Ecol. Prog. Ser. 329, 267-279. https://doi.org/10.3354/ meps329267.

Borges, L., 2000. Age and growth of the snipefish, Macrorhamphosus spp., in the Portuguese continental waters. J. Mar. Biol. Assoc. U. K. 80, 147-153. https://doi org/10.1017/S0025315499001666.

Caddy, J.F., Rodhouse, P.G., 1998. Cephalopod and groundfish landings: evidence for ecological change in global fisheries? Rev. Fish Biol. Fish. 8, 431-444. https://doi. org/10.1023/A:1008807129366.

Calenge, C., 2015. Home range estimation in R: the adehabitatHR package. R vignette. https://doi.org/10.1111/j.1365-2656.2006.01186.x.

Christiansen, B., Martin, B., Hirch, S., 2009. The benthopelagic fish fauna on the summit of Seine Seamount, NE Atlantic: composition, population structure and diets. Deep. Res. Part II Top. Stud. Oceanogr. 56, 2705-2712. https://doi.org/10.1016/j. dsr2.2008.12.032.

Church, G.E., Furness, R.W., Tyler, G., Gilbert, L., Votier, S.C., 2018. Change in the North Sea ecosystem from the 1970s to the 2010s: great skua diets reflect changing forage fish, seabirds, and fisheries. ICES J. Mar. Sci. https://doi.org/10.1093/icesjms/ fsy 165.

Cropper, T.E., Hanna, E., Bigg, G.R., 2014. Spatial and temporal seasonal trends in coastal upwelling off Northwest Africa, 1981-2012. Deep. Res. Part I Oceanogr. Res. Pap. 86, 94-111. https://doi.org/10.1016/j.dsr.2014.01.007.

Davenport, R., Neuer, S., Hernandez-Guerra, A., Rueda, M.J., Llinas, O., Fischer, G., Wefer, G., 1999. Seasonal and interannual pigment concentration in the Canary Islands region from CZCS data and comparison with observations from the ESTOC. Int. J. Rem. Sens. 20, 1419-1433. https://doi.org/10.1080/014311699212803.

Delgado, J., Amorim, A., Gouveia, L., Gouveia, N., 2018. An Atlantic journey: the distribution and fishing pattern of the Madeira deep sea fishery. Reg. Stud. Mar. Sci. https://doi.org/10.1016/j.rsma.2018.05.001.

Edwards, M., Beaugrand, G., Helaouët, P., Alheit, J., Coombs, S., 2013. Marine ecosystem response to the atlantic multidecadal oscillation. PloS One 8, 1-5. https://doi.org/ 10.1371/journal.pone.0057212.

Ehrich, S., 1976. Zur Taxonomie, Ökologie und Wachstum von Macroramphosus scolopax (Linnaeus, 1758) (Pisces, Syngnathiformes) aus dem subtropischen Nordostatlantik. Berichte der Dtsch. wissenschaftlichen Kommission für Meeresforsch. 24, 251-266.

Ehrich, S., John, H.-C., Westhaus-Ekau, P., 1987. Southward extension of the reproductive range of Macroramphosus scolopax in the upwelling area off North-West 
Africa. S. Afr. J. Mar. Sci. 5, 95-105. https://doi.org/10.2989/ 025776187784522298.

FAO, 2019. Report of the FAO working group on the assessment of small pelagic fish off northwest Africa. Banjul, the Gambia, 26 June-1 July 2018. FAO Fisheries and Aquaculture Report No. R1247. Rome. Licence: CC BY-NC-SA 3.0 IGO. Downloaded from. http://www.fao.org/publications/card/en/c/CA4121B.

FAO, 2018. Fishery Committee for the Eastern Central Atlantic, Status summary for small pelagic stocks in the northern area of the eastern central Atlantic - CECAF. Abidjan, Côte d'Ivoire, 23-26 October 2018. FAO Fisheries and Aquaculture Report. CECAF/ SSCVIII/2018/2. Downloaded from. http://www.fao.org/fi/static-media/Meetin gDocuments/CECAF/CECAF-SSC8/default.htm.

Fock, H.O., Matthiessen, B., Zidowitz, H., Westernhagen, H.V., 2002a. Diel and habitatdependent resource utilisation by deep-sea fishes at the Great Meteor seamount: niche overlap and support for the sound scattering layer interception hypothesis. Mar. Ecol. Prog. Ser. 244, 219-233. https://doi.org/10.3354/meps244219.

Fock, H.O., Uiblein, F., Von Westernhagen, H., 2002b. Biodiversity and species-environment relationships of the demersal fish assemblage at the Great Meteor Seamount (subtropical NE Atlantic), sampled by different trawls. Mar. Biol. 141, 185-199. https://doi.org/10.1007/s00227-003-1281-7.

Granadeiro, J.P., Monteiro, L.R., Furness, R.W., 1998a. Diet and feeding ecology of Cory's shearwater Calonectris diomedea in the Azores, north-east Atlantic. Mar. Ecol. Prog. Ser. 166, 267-276. https://doi.org/10.3354/meps166267.

Granadeiro, J.P., Silva, M.A., 2000. The use of otoliths and vertebrae in the identification and size-estimation of fish in predator-prey studies. Cybium 24, 383-393.

Grebmeier, J.M., Overland, J.E., Moore, S.E., Farley, E.V., Carmack, E.C., Cooper, L.W., Frey, K.E., Helle, J.H., McLaughlin, F.A., McNutt, S.L., 2006. A major ecosystem shift in the northern Bering sea. Science 311, 1461-1464. https://doi.org/10.1126/ science. 1121365 .

Gulland, J.A., Garcia, S., 1984. Observed patterns in multispecies fisheries. In: Exploitation of Marine Communities. Springer, Heidelberg, Berlin, pp. 155-190. https://doi.org/10.1007/978-3-642-70157-37.

Hastie, L., Pierce, G., Wang, J., Bruno, I., Moreno, A., Piatkowski, U., Robin, J., 2009. Cephalopods in the North-eastern Atlantic: species, biogeography, ecology, exploitation and conservation. In: Oceanography and Marine Biology: an Annual Review, pp. 111-190. https://doi.org/10.1201/9781420094220.ch3.

Hermida, M., Delgado, J., 2016. High trophic level and low diversity: would Madeira benefit from fishing down? Mar. Pol. 73, 130-137. https://doi.org/10.1016/j. marpol.2016.07.013.

Kowalczyk, N., Chiaradia, A., Preston, T., Reina, R.D., 2014. Linking dietary shifts and reproductive failure in seabirds: a stable isotope approach. Funct. Ecol. 28, 755-765. https://doi.org/10.1111/1365-2435.12216.

Lopes, M., Murta, A.G., Cabral, H.N., 2006. The ecological significance of the zooplanktivores, snipefish Macroramphosus spp. and boarfish Capros aper, in the food web of the south-east North Atlantic. J. Fish. Biol. 69, 363-378. https://doi.org/ 10.1111/j.1095-8649.2006.01093.x.

Lopes, P.C., Farinha, A., 1996. Occurrence of the eggs and larvae of the snipefish Macroramphosus scolopax in the western coast of the Iberian Peninsula. Int. Counc. Explor. Sea (CM Pap. Reports) CM 1996/L 1-10.

Marques, V., Chaves, C., Morais, A., Cardador, F., Stratoudakis, Y., 2005. Distribution and abundance of snipefish (Macroramphosus spp.) off Portugal (1998-2003). Sci. Mar. 69, 563-576. https://doi.org/10.3989/scimar.2005.69n4563.

Martins, I., Pereira, J.C., Ramos, J.A., Jørgensen, S.E., 2004. Modelling the effects of different quality prey fish species and of food supply reduction on growth performance of Roseate Tern chicks. Ecol. Model. 177, 95-106. https://doi.org/ 10.1016/j.ecolmodel.2004.02.002.

Montevecchi, W.A., 2007. Binary dietary responses of northern gannets Sula bassana indicate changing food web and oceanographic conditions. Mar. Ecol. Prog. Ser. 352, 213-220. https://doi.org/10.3354/meps07075.

Morais, R., 1981. Sobre a pescaria e biologia do apara-lápis ou trombeteiro. Bol. Inst. Nac. Invest. Pescas 6, 5-35.

Morato, T., Solà, E., Grós, M., Menezes, G., 1999. Diets of Forkbeard (Phycis Phycis) and conger Eel (Conger conger) off the Azores during Spring of 1996 and 1997. Archipélago Life and M, pp. 51-64.

Morato, T., Solà, E., Grós, M.P., Menezes, G., 2003. Diets of thornback ray (Raja clavata) and tope shark (Galeorhinus galeus) in the bottom longline fishery of the Azores, northeastern Atlantic. Fish. Bull. 101, 590-602.
Morato, T., Varkey, D.A., Damaso, C., Machete, M., Santos, M., Prieto, R., Santos, R.S., Pitcher, T.J., 2008. Evidence of a seamount effect on aggregating visitors. Mar. Ecol. Prog. Ser. 357, 23-32. https://doi.org/10.3354/meps07269.

Mougin, J.L., Mougin, M.C., 1998. Maximum diving depths of Cory's shearwater in the course of its feeding trips during incubation. Rev. Ecol. Terre Vie 53, 69-76.

Oksanen, J., Guillaume Blanchet, F., Kindt, R., Legendre, P., Minchin, P.R., O'Hara, R.B., Simpson, G.L., Solymos, P., Henry H, M., Stevens, H.W., 2019. Community Ecology Package. R vignette.

Palumbi, S.R., 1996. Nucleic acids II: the polymerase chain reaction. In: Molecular Systematics, pp. 205-247.

Pebesma, E.J., Bivand, R.S., 2005. Classes and methods for spatial data in R. R. News 5 (2), 9-13. https://CRAN.R-project.org/doc/Rnews/.

Pethybridge, H.R., Young, J.W., Kuhnert, P.M., Farley, J.H., 2015. Using stable isotopes of albacore tuna and predictive models to characterize bioregions and examine ecological change in the SW Pacific Ocean. Prog. Oceanogr. 134, 293-303. https:// doi.org/10.1016/j.pocean.2015.03.001.

Phillips, R.A., Xavier, J.C., Croxall, J.P., 2003. Effects of satellite transmitters on albatrosses and petrels. Auk 120, 1082-1090.

Pitcher, T.J., Morato, T., Hart, P.J.B., Clark, M.R., Haggan, N., Santos, R.S., 2007. Seamounts: Ecology, Fisheries \& Conservation. Blackwell Publishing. https://doi. org/10.1002/9780470691953.

Ramos, J.A., Solá, E., Monteiro, L.R., Ratcliffe, N., 1998. Prey delivered to roseate tern chicks in the Azores. J. Field Ornithol. 69, 419-429.

Riera, F., Grau, A., Grau, A.M., Pastor, E., Quetglas, A., Pou, S., 1999. Ichthyofauna associated with drifting floating objects in the Balearic Islands (western Mediterranean). Sci. Mar. 63, 229-235. https://doi.org/10.3989/scimar.1999.63n34239.

Salvanes, A.G.V., Kristoffersen, J.B., 2001. Mesopelagic fishes. In: Encyclopedia of Ocean Sciences. Academic Press, pp. 1711-1717. https://doi.org/10.1016/B978012374473-9.00012-6.

Shealer, D.A., 2002. Foraging behaviour and food of seabirds. In: Biology of Marine Birds. CRC Press, pp. 137-177.

Silva, A., 1999. Feeding habits of John Dory, Zeus faber, off the Portuguese continental coast. J. Mar. Biol. Assoc. U. K. 79, 333-340. https://doi.org/10.1017/ S002531549800037X.

Stromme, T., Charouki, N., Alvheim, O., 2006. Survey of the Pelagic Fish Resources off North West Africa. Part III: Cape Blanc - Cape Sim.

Thiaw, M., Auger, P.-A., Ngom, F., Brochier, T., Faye, S., Diankha, O., Brehmer, P., 2017. Effect of environmental conditions on the seasonal and inter-annual variability of small pelagic fish abundance off North-West Africa: the case of both Senegalese sardinella. Fish. Oceanogr. 26, 583-601. https://doi.org/10.1111/fog.12218.

Vassilopoulou, V., Siapatis, A., Christides, G., Bekas, P., 2005. The biology and ecology of juvenile pilotfish (Naucrates ductor) associated with Fish Aggregating Devices (FADs) in eastern Mediterranean waters. Mediterr. Mar. Sci. 5, 61-70.

Veit, R.R., Harrison, N.M., 2017. Positive interactions among foraging seabirds, marine mammals and fishes and implications for their conservation. Front. Ecol. Evol. 5, 121. https://doi.org/10.3389/fevo.2017.00121.

Velarde, E., Tordesillas, M.S, Vieyra, L., Rocio Esquivel, L.V., 1994. Seabirds as indicators of important fish populations in the Gulf of California. CALCOFI (Calif. Coop. Ocean. Fish. Investig.) Rep. 35, 137-143.

Waap, S., Symondson, W.O.C., Granadeiro, J.P., Alonso, H., Serra-Gonçalves, C., Dias, M. P., Catry, P., 2017. The diet of a nocturnal pelagic predator, the Bulwer's petrel, across the lunar cycle. Sci. Rep. 7 https://doi.org/10.1038/s41598-017-01312-3.

Wienerroither, R., Uiblein, F., Bordes, F., Moreno, T., 2009. Composition, distribution, and diversity of pelagic fishes around the canary islands, eastern central atlantic. Mar. Biol. Res. 5, 328-344. https://doi.org/10.1080/17451000802478055.

Wilson, R., 1984. An improved stomach pump for penguins and other seabirds. J. Field Ornithol. 55, 109-112.

Xavier, J.C., Magalhães, M., Mendonça, A.S., Antunes, M., Carvalho, N., Machete, M., Santos, R.S., Paiva, V.H., Hamer, K.C., 2011. Changes in diet of Cory's shearwaters Calonectris diomedia breeding in the Azores. Mar. Ornithol. 39, 129-134. https://doi. org/10.3354/meps166267.

Zidowitz, H., Fock, H.O., 2004. Trophic ecology of Zenopsis conchifer (lowe, 1852) at the great meteor seamount (subtropical north-east Atlantic). Arch. Fish. Mar. Res. 51, 279-286. 